\title{
Moisture damage in Finnish wooden houses
}

Received (in revised form): 23rd September, 2005

\section{Jari Heikkilä}

is a doctor of science (technology) and works in the Department of Architecture at the University of Oulu as a building science lecturer and a docent of wood construction. Since its establishment in 1995 , he has been a member of a research group called Wood Studio. His research has dealt with wood construction, wood architecture and, in recent years, massive wood construction methods in particular. He has written books as well as popular and scientific articles on these subjects. He has given lectures on wood construction and wood architecture in Finland as well as in different parts of the world.

\section{Abstract}

Finland is one of the world's leading countries in terms of wood construction. Traditionally, wooden houses in Finland have been mainly single-family homes. Since the late 1990s, Finland has invested strongly in wood construction and has tried to increase the use of wood in all types of buildings. Wood structures nevertheless have been met with some suspicion because not all experiences with wood in construction have been positive. Serious damage from moisture has been found in 82 per cent of singlefamily homes built since the 1950s. The majority of the damage seen today in wooden buildings is concentrated in wet areas, base floor structures and the joints between the base floor and wall structures. In order for timber construction to become common again, people must learn about the causes of the damage and be able to build sound and long-lasting timber structures. One step in this effort is to renew the building regulations related to moisture.

\section{Keywords:}

timber structures, moisture damage, healthy buildings, long-term durability

\section{BACKGROUND}

Finland is one of the world's leading countries in terms of wood construction because of the country's wealth of timber resources. Finland is the most heavily forested country in Europe, with 76 per cent of its surface area being covered in forest. To date the growth of Finland's forests has outpaced the harvest, and the annual utilisation of the forest clearly could be increased. The increased use of wood would create new jobs, boost Finland's exports and improve the economy. According to estimates, it would be possible to increase Finland's export income from timber by as much as double the current level. It is for this reason that the Finnish state authority began investing significantly in the development of wood construction and research in the late 1990s. The aim of this FIN-90014, Oulu, Finland 


\section{A prolonged humidity causes mould and decay in wood}

successful because wood has risen to a more significant status in Finnish construction.

Wood is an excellent construction material and its use has a long tradition. History shows that wood can be used for building durable and long-lasting structures, but it nevertheless has its poor qualities. Doubts also have been directed at the development of wood structures, with the strongest centred on their combustibility as well as their long-term durability. As a result of prolonged moisture, timber structures become mouldy, decay and spoil. There are examples of this damage in all sorts of timber structures. In order for timber construction to succeed and increase, people must learn to make long-lasting and durable structures from wood.

The weaknesses of wood include its susceptibility to decay, moisture expansion, anisotropicism and combustibility. Therefore, if one wishes to build with wood, it is important to know its biological and physical properties and its behaviour in different conditions. In construction, it is of utmost importance that sufficient attention is paid to the protection of wood from damage. This must be taken care of structurally by placing the timbers - of appropriate strengths and qualities — into the right places.

Wood begins to become damaged if its moisture content is over 20 per cent for long periods of time. In such a situation the relative humidity of the surrounding air is more than 80 per cent. Wood begins to grow mould within a few months if the relative humidity of the surrounding air stays over 80 per cent. A humidity level of 70 per cent can be considered to be the critical value. When the relative humidity of air rises above 90 per cent, the wood begins to decay. Another condition for the moulding and decaying of wood is that the air temperature is between $0^{\circ} \mathrm{C}$ and $40^{\circ} \mathrm{C}$. Mould spores and rot fungi need oxygen and nutrients to operate and these are generally present in sufficient quantities in both the wood and the surrounding air.

It is known that approximately 80 per cent of all damage in woodstructured houses is caused by moisture (Kääriäinen et al., 1998). The typical reasons for moisture damage in wooden buildings include the following, among others:

- wooden structures touching the ground;

- wooden structures extending too close to the ground;

- missing façade-protecting eaves;

- insufficient preparations for changes in shape caused by moisture, resulting in swelling damage and cracking from drying;

- capillary water flow from connected building sections has not been stopped;

- inadequate waterproofing and ventilation in wet areas .

It can be seen from centuries-old, preserved timber structures that wood certainly remains preserved even without treatment so long as it has structural protection. The requirement for long-lasting wood is to keep its moisture content below 20 per cent. Wood is a demanding building material that requires better planning, construction and maintenance than many other materials. 


\section{WOODEN BUILDING STOCK IN FINLAND}

Wood has always been a natural building material in Finland. In old constructions, wood was used in a multitude of ways because there were not many other materials available or they were too expensive. Until the beginning of the 20th century, wood was virtually the only building material, and was used as both load-bearing and supplementary components of buildings. The traditional Finnish building method was the horizontal log structure where massive logs served as the walls' loadbearing structure and thermal insulation as well as interior and exterior cladding material. In the beginning of the 1900s, the American-style, lightweight timber frame was brought to Finland and, by the 1930s, it had virtually replaced $\log$ structures due to its affordability, speed of construction and thermal insulation qualities (see Figure 1). Finnish wood construction today is mainly comprised of timber-framed buildings.

Until the 1800s, Finnish towns were also log-structured, wood towns. As a result of the great town fires of the early 1800s, stone became the material used for towns. The stone buildings gradually grew to many storeys and became larger than the wooden buildings. Construction methods were determined by fire safety regulations, which limited wooden structures to two storeys. As a result, the use of wooden structures in Finland has been limited almost exclusively to single-family homes. Single-family houses have kept their position today. In 2005, the share of new homes built from wood was 85 per cent, with 70 per cent of row

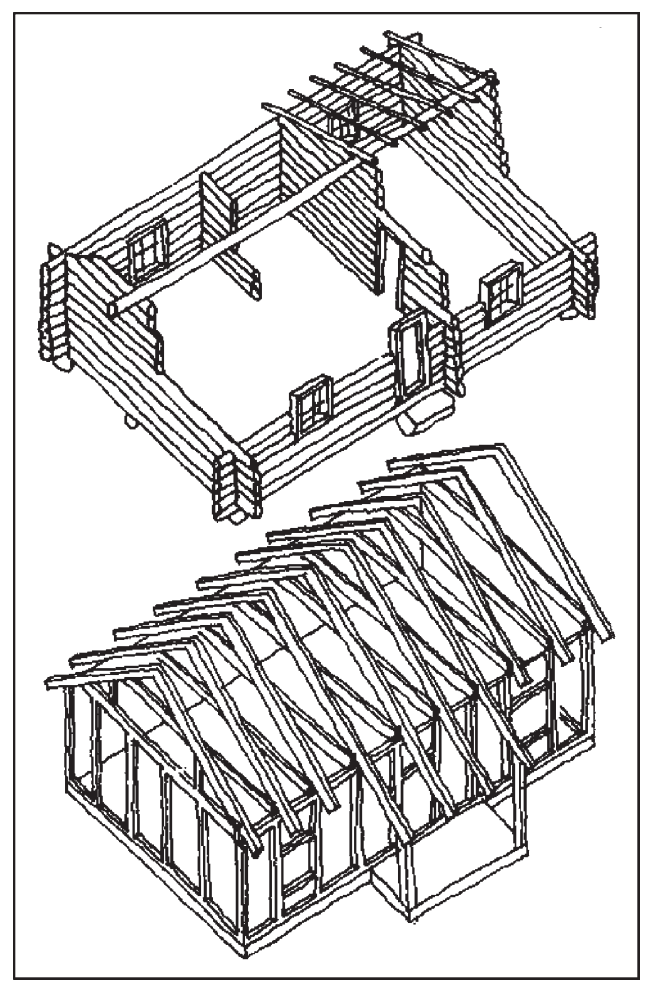

Figure 1: The lightweight timber frame has replaced traditional massive log structures in Finnish wood construction 
Wet rooms and water pipes have increased the risk of moisture damage in houses

\section{The building method used in the 1960 s and 1970 s has been especially dangerous}

houses and 100 per cent of holiday houses being made of wood (Rakennustutkimus RTS Oy, 2005; personal communication). Additionally, wood has been used to build small apartment buildings and small public and commercial buildings. In the 1990s, fire regulations in Finland were revised to coincide with the principles of pan-European regulations. The restrictions set by building codes for the use of wooden structures were loosened to the extent that wood now can be used to build three-four-storey residential and workplace buildings, and even particularly large projects can be realised with wooden frames. It appears as though the percentage of structures made from wood in large-scale construction will remain quite low despite the removal of fire safety barriers.

Sawdust was originally used as a filling for timber-framed structures, so the structures functioned similarly to traditional log walls with regard to the physics of moisture. When, in the 1960s, builders switched to using industrial mineral wool insulation, the operational principles of wooden structures changed. When using mineral wool, which insulates heat well and absorbs moisture poorly, wooden structures require a separate sealing film in order to ensure that air and vapour do not penetrate the structure.

Perhaps the most significant change affecting the moisture techniques used in wooden buildings occurred when washing areas and saunas were moved from outbuildings or cellars into homes. This caused a significant increase in moisture strain and resulted in the placement of pipes, susceptible to leaking, into structures. In addition, one must remember the special characteristic of the Finnish sauna culture: water use is not limited to a bath or a shower cubicle, instead all wall and floor structures of wet areas are exposed to splash water. This increase in the use of water has happened gradually and unnoticed. Building methods have stayed the same, structural solutions for wet areas have hardly been developed and ventilation has not been increased. One fateful mistake in wooden house construction, made in the 1960s, when water pipes were embedded into structures, has been rectified, however. The hidden pipes were able to leak for a long time before the damage was noticed. After bitter experience in the 1980s, pipes were required to be placed in visible areas so that their condition could be monitored.

In addition to the changes in thermal insulation and the emergence of wet areas, other changes related to structure and moisture techniques have also occurred in Finnish wooden houses. A wooden base floor with a ventilated crawl space underneath was part of traditional Finnish wood construction. During the reconstruction period of the 1940s and 1950s, cellars were encouraged. Wooden houses had a stone-structured cellar level, thanks to which the wooden floor structure could be ventilated (see Figure 2). When, in the 1950s, it was discovered that low foundations could be built without danger of frost damage, new houses began to be built without cellars, and homes, including their service spaces, were built on one level. As a result, architectural ideals by the beginning of the 1960s also changed and houses were designed to be low and to emphasise horizontal direction (see Figure 3). Builders began using ground slabs for 


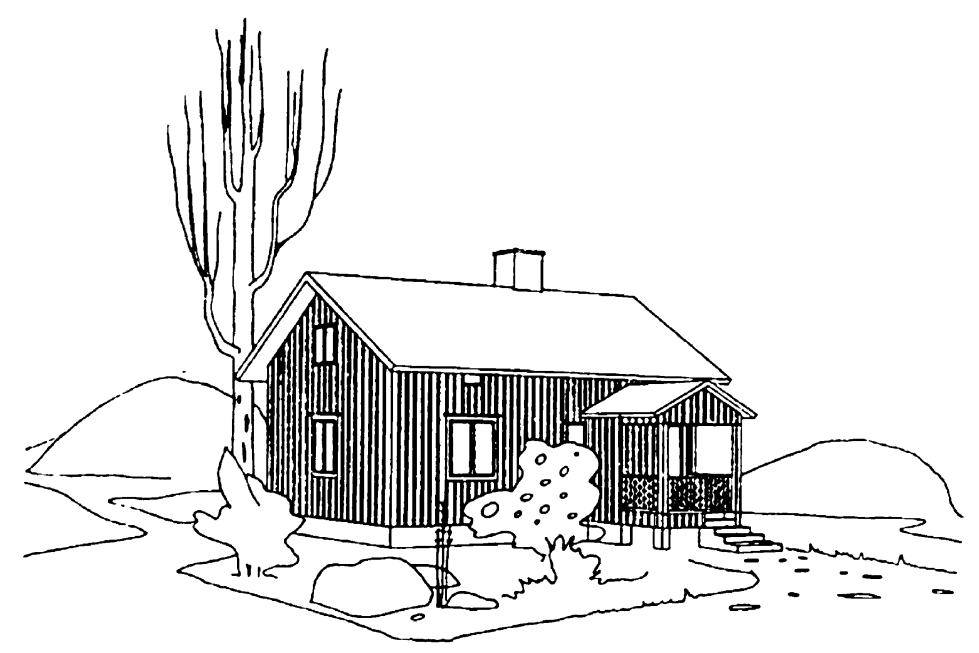

Figure 2: A traditional wooden house from the 1950s

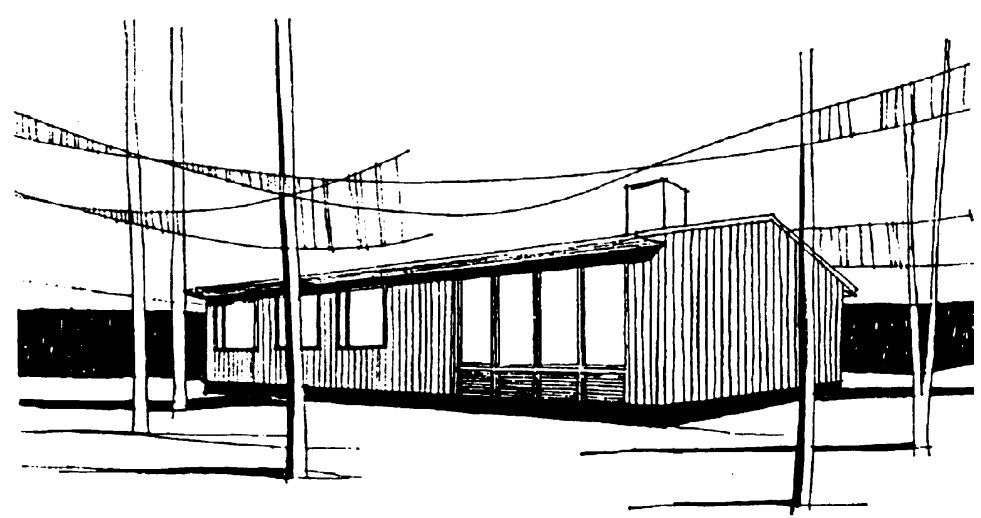

Figure 3: A modern, one-level wooden house from the 1960 s

flooring and floors were designed to be as close to the ground as possible. In wooden houses this resulted in the bottom of exterior walls extending underground, and led to the so-called false-footing solution, which has proved to be one of the worst mistakes of wooden construction with respect to moisture techniques. Even today this building method has not been discontinued entirely, even though the faultiness of the method was demonstrated as early as 25 years ago.

Based on the same architectural aim, designers wanted roofs to be as gently sloped as possible. In the beginning of the 1970s, new wooden houses turned into completely flat-roofed buildings (see Figure 4). This building method quickly proved to be a fateful mistake in the northern climate of Finland. As a counteraction to the problems that arose, flat roofs on single-family houses were rejected entirely and, since the 1980s, Finnish single-family houses again have had an inclined ridge roof. Nearly all flat-roofed, single-family houses have been changed into ridge-roofed buildings in later repairs. 


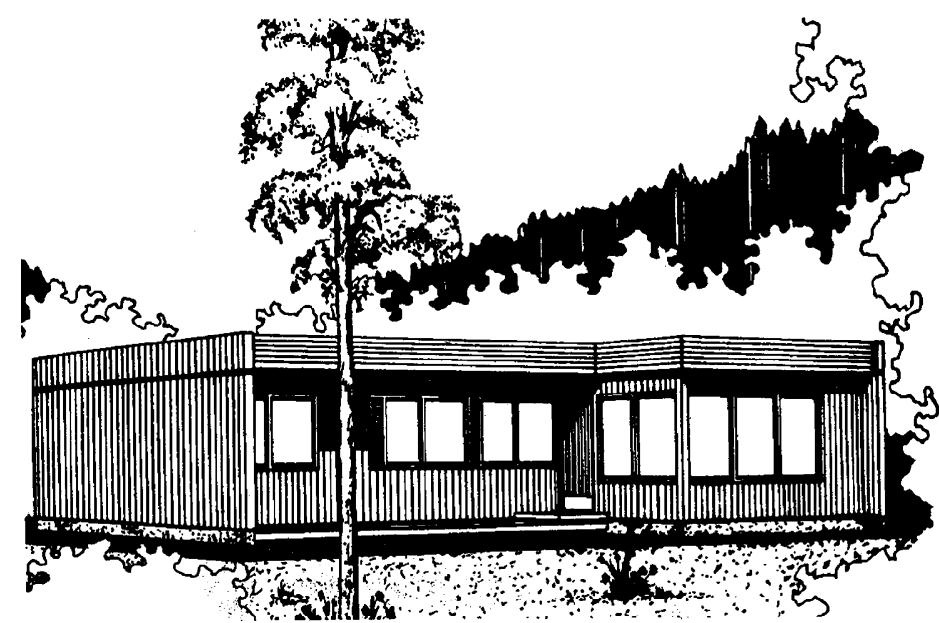

Figure 4: A wooden house with a flat roof from the 1970s

\section{CONDITION OF AND TYPICAL MOISTURE DAMAGE IN FINNISH WOODEN HOUSES}

The amount of moisture damage in Finnish wooden buildings can be examined on the basis of studies made of single-family houses. Nearly all Finnish wooden houses are single-family homes. The large amount of moisture damage in Finnish single-family houses is alarming. Field tests conducted in 1995 indicate that 82 per cent of single-family houses built after 1950 have moisture damage. The fact that nearly 500,000 houses, or 55 per cent of Finnish single-family homes, are in need of immediate repair underlines the serious nature of moisture damage (Partanen et al., 1995).

The Partanen et al. (1995) study shows that there is moisture damage in wooden houses of all ages; however, it is clear that most of the moisture damage appears in homes from the 1960s and 1970s, when new types of material and different architectural solutions were used. Based on the Partanen et al. (1995) study it appears that something has been learned from the errors because the amount of moisture damage in houses built since the beginning of the 1980s has decreased somewhat. Yet on the basis of the Partanen et al. (1995) study it can be concluded that the risk of moisture damage in wooden buildings is always high.

When examining moisture damage in wooden houses of different ages it is found that the damage is strongly dependent on the construction method used. The greatest moisture problem in houses from the 1950s is seepage along the cellar walls. Other moisture damage is related to the ageing of roofs and pipes. The actual wooden structures of these houses are in very good condition, probably because the wood is located sufficiently high above ground level, roofs are steeply inclined, the buildings have protective eaves and do not have actual wet areas inside the wooden frame, these being located in the stone-structured cellars. In houses from the 1960s, however, there is plenty of damage in all parts of the building, mostly located in wooden roof structures due to leaking in the gently sloping roofs. Roof leaks are typically concentrated 
around the bases of roof ducts and occur mostly in early spring. Floor structures also exhibit a large amount of damage as a result of leaks from pipes embedded into them as well as from external surface water.

There is also an abundance of moisture damage in the floors and walls of wet areas that have not been waterproofed. The worst moisture damage in houses from the 1970s is roof damage, resulting from leaking in flat roofs, and is focused on roof ducts. Another significant group of damaged areas encompass the walls and floors in wet areas. Floor damage is also caused by surface water from outside. As late as the 1970s builders still embedded pipes into floor structures, and piping damage is another significant problem group. Moisture damage in roofs no longer appears in wooden houses from the 1980s because the houses have been built with sufficiently inclined roofs. Damage in the walls and floors of wet areas, however, continues to be common. Floor damage caused by surface water from outside also continues to occur (Partanen et al., 1995).

When examining damage in different parts of a building it can be linked to four reasons: leaking of gently sloping roofs, floor damage caused by wet areas, floor damage caused by building too close to the ground and pipe damage. In the Partanen et al. (1995) study, more than 70 per cent of flat roofs were damaged. Remarkably, there was also damage found in 35 per cent of the steepest ridge roofs. This damage was usually related to sheet metal roofing and defective sealing at its joints. Damage in wet areas existed in 42 per cent of all the houses examined. Fifty per cent of all floor damage was caused by outside surface water, while damage from pipes appeared to correlate directly with the age of the piping (Partanen et al., 1995). Pipe leaks are also common in new houses, however. In 1995 water leaks were found in 17,000 single-family houses in Finland (Määttä and Kannisto, 1997).

According to Partanen et al. (1995), errors in work, material and design

Errors in work, material and design are the main reasons for moisture damage are the most significant reasons behind moisture damage. Thus half (4060 per cent) of all moisture damage is caused during the building stage. The ageing and defective maintenance of building parts also leads to damage. Outright mistakes in use also occur. The total sum of repair costs for moisture damage in single-family houses is estimated to be $€ 1,200$ for each house (Partanen et al., 1995).

The large amount of historic moisture damage indicates that the use of wooden structures is especially problematic. But one must be critical in this regard. Moisture damage is more related to the building method employed than the material used. The cellar walls of houses from the 1950s are stone structures and their waterproofing problems are not related to wood. The roof leaks from the 1960s and 1970s were caused by inadequate incline and waterproofing materials of poor quality. As such the damage is not related to the use of wood as a building material because common experience shows that damage occurs in the same way in the flat roofs of stone buildings. Neither can wooden structures be considered to be the only cause of damage in wet areas because the prime cause of damage is defective waterproofing. Moisture damage has also occurred in stone-structured wet areas where the structures do not have a waterproofing 
layer; however, the use of wood in wet areas results in damage that is greater and more difficult to repair. Pipe leaks are caused by the ageing of materials and thus are not problems particular to wooden buildings because pipes leak in stone houses too. Damage to floor structures is caused by outside surface water and building too close to the ground, but damaged floors also have been made of concrete slabs. Based on these facts it can be inferred that the role of the actual wood material in the worst damage seen in wooden houses is insignificant. This assumption is also confirmed by the fact that, during an equivalent time period to the 1995 study, serious moisture damage was found in 60 per cent of multi-storey, stone-structured buildings (Koivisto et al., 1996).

Damage to the façades of Finnish wooden structures also has been clarified using field studies. On the whole, moisture damage to wooden façades is minor compared with the previously described problems and does not appear in the extensive moisture damage study of Partanen et al. (1995). But damage to wooden façades is expressly typical of wood. In fact, damage to wooden façades in Finland has been considered so important that builders have even tried to avoid using wood as façade material entirely. Damage to wooden façades is caused mainly by moisture. The greatest damage either occurs as a result of wood being too close to the ground or even in direct contact with the ground, or because façade-protecting eaves are missing. Damage also occurs when wooden structures have been in direct contact with foundation structures. In addition, the lack of ventilation space behind timber cladding causes moisture damage, especially if the cladding is impervious. The use of timber that is too thin results in contortion and cracking of the wood when subjected to the strain of moisture. The details of wooden façades are often made carelessly. The cladding may contain horizontal surfaces that hold water. The bottom corner of protruding cladding may lack drip moulding allowing water to funnel into the structure. Extensions, joints and corners as well as the bottoms of vertical boards are often damaged. Boards that are attached too closely to each other do not allow the wood to enlarge, or boards nailed too close to the end of the timber split under moisture strain (Soikkeli, 1999). The use of wood in outside spaces and inside in wet areas requires planning and building details to be more thorough than with other materials in order to avoid such damage.

In Finland there has been continuous and extensive public discussion in recent decades concerning the quality of construction. The reason for this debate has been the abundance of moisture and mould damage and the resulting internal air problems in buildings. In addition to single-family houses, multi-storey apartment buildings as well as public and commercial buildings have suffered from serious moisture damage. Builders see two important reasons behind the quality problems: tightened construction schedules and a shortage of professionally skilled workers. The quality of planning is also considered to be low. At the same time, however, it must be noted that Finland is not alone with its construction quality and moisture problems and international evaluations of the quality of Finnish construction consider it to be quite decent. 
In the discussion on quality it has been noted that expertise in building physics appears to be emerging as a key area of research in the Finnish construction industry. Moisture damage can be avoided only through significant investment in building physics research and development. Through such research and development it will be possible to create structural solutions that are more reliable and secure, thereby being especially pertinent to wood construction, which is nationally important to Finland.

\section{WAYS TO AVOID DAMAGE TO WOODEN STRUCTURES}

In Finland, moisture damage in wooden buildings has not been eliminated, even though building physics research has been undertaken and information about sound solutions has been available for a long time. Despite the increase in information and attention paid to quality in singlefamily house construction, the same mistakes are continuously repeated. In new wooden buildings, 60-80 per cent of moisture damage risk concerns base floor structures and wet areas (Kääriäinen et al., 1998). So far, it has been possible to eliminate damage to roofs and piping systems. In fact, base floor structures, the joints between floors and exterior walls and wet room structures are the most difficult areas to design to prevent moisture damage. By working on the careful planning, construction and maintenance of these three structures, it is possible to ensure long-lasting and safe wood construction (Kääriäinen et al., 1998).

The basic requirement for base floor structures is to raise the floor

The floor must be high enough from the ground surface to a sufficient height from the ground (see Figures 5 and 6). Under a ground-supported floor it is necessary to have an effective layer that stops the capillary rise of water. Moisture strain in the base floor and foundations can be reduced by making the ground slope away from the building and by making subsurface drainage around the building.

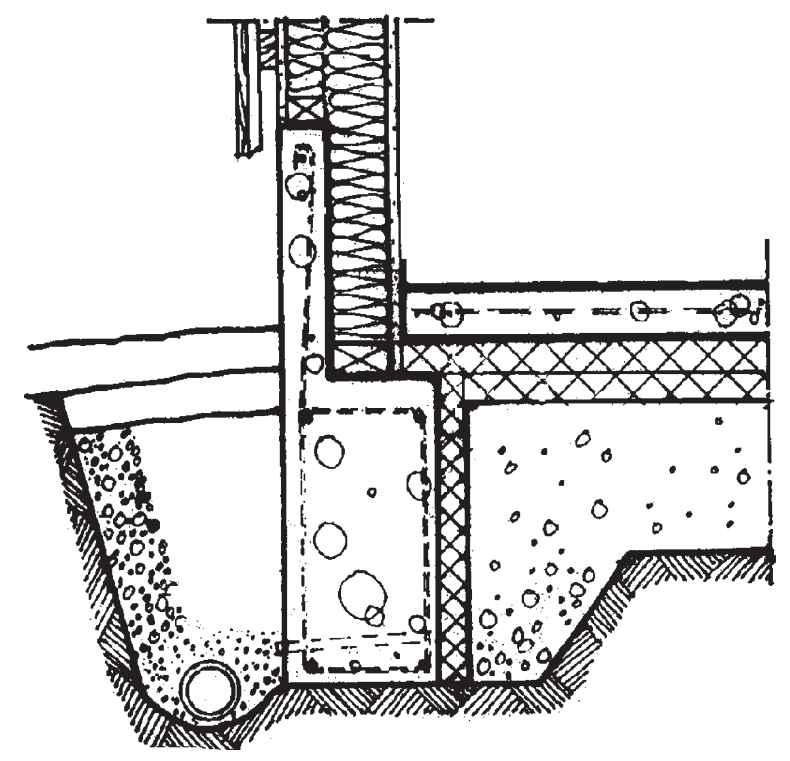

Figure 5: The dangerous false-footing solution: the floor and the ground are on the same level and the bottom of the wooden wall extends underground 
Wet rooms should be done from stone structures

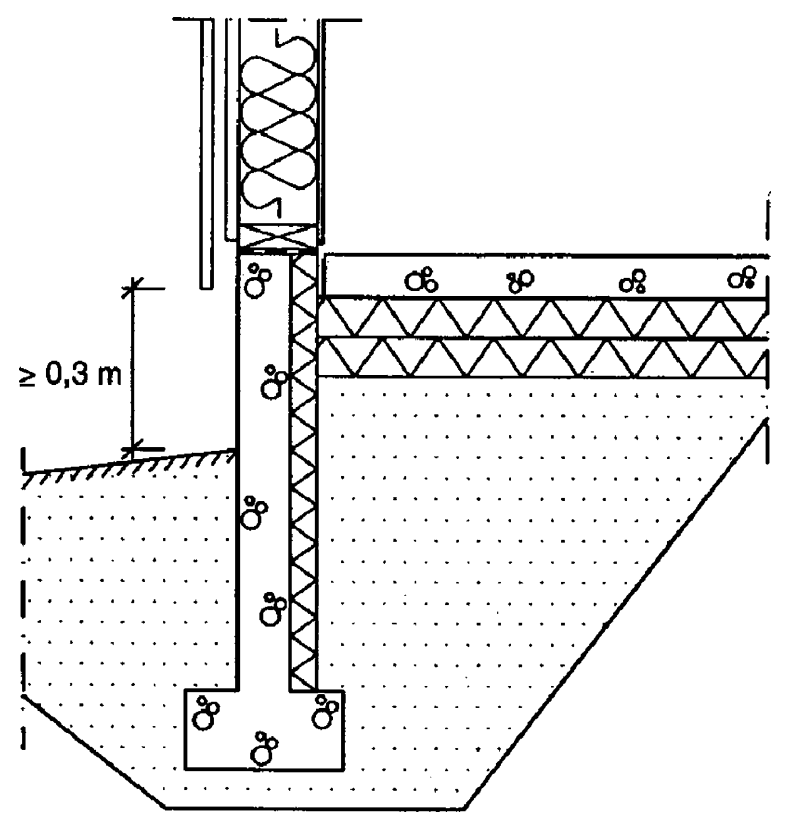

Figure 6: A safe solution because the floor level is high enough from the ground

The crawl space under a wood-structured base floor must be well ventilated. Thermal insulation in ground-supported floors must be placed under the concrete slab. Concrete slabs must be made early enough for them to dry adequately before coating and so that partition walls can be built on top of the concrete. Wet areas should be built from stone as far as possible, even in wooden buildings (Figure 7). The majority of wet-area problems result from light timber-frame structures and their movements.

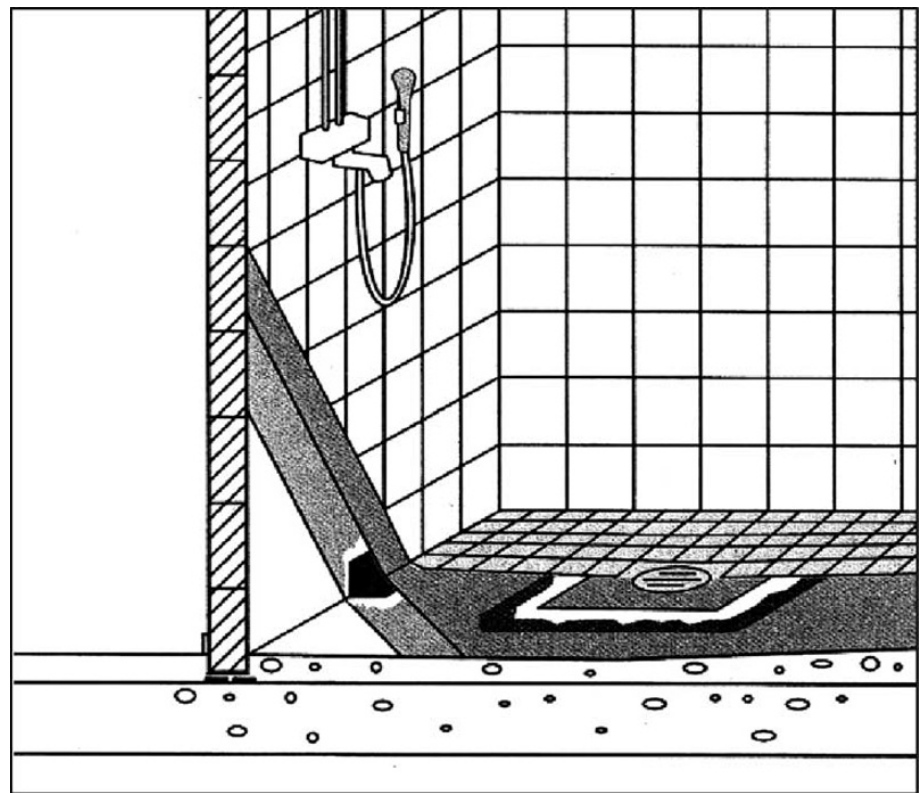

Figure 7: A safe wet room because both the walls and the floor are waterproofed and the basic structures are made from stone 
In wet areas it is necessary to waterproof the floor reliably as well as the walls. With these fairly simple solutions it is possible to prevent the majority of moisture problems in wood-structured, single-family houses (Kääriäinen et al., 1998).

In addition, when it is ensured that only stone structures are used in cellars, pipes are installed in visible places, an adequately inclined roof is designed and façade-protecting eaves are built on the building, a sound and risk-free construction method is quite nearly achieved.

\section{STEPS FOR PREVENTING DAMAGE TO WOODEN STRUCTURES}

In maintaining its building stock, Finland has experienced the demanding nature of wooden structures in single-family houses in a rather difficult manner. The building stock that has been preserved best indicates that the traditional building method in use for centuries has appreciated the risks of wooden structures and produced sound and long-lasting designs. Traditionally, wooden structures were raised sufficiently high from the ground and buildings were protected with a ridge roof and eaves. The greatest damage and problems with wooden structures are connected with the modern architectural period and the architectural experiments of the second half of the 1900s in particular. In these experiments, wood structures were pressed to the ground. The cube-shaped style of building masses favoured by modern architecture brought flat roofs even to wooden buildings and rejected protective eaves. In practical terms these experiments quickly proved to be mistakes.

Plenty of practical knowledge of wet-area damage has been learned too. Wet areas have moved quite unnoticed into homes over recent decades and provisions have not been made in building methods for heavy water usage or the increase in moisture strain. People have learned to pay attention to the design of wet-area structures only after heavy structural repairs.

Because mere research and education activity has not led to changes in construction methods, Finland has decided to engage in rather strong measures to get rid of unnecessary moisture problems based on ignorance. The chosen tool is building codes, which cover all areas of construction. In 1998, the section dealing with moisture technique activity was renewed in the national building code of Finland. These regulations, which became effective in the summer of 1999, require the floor surface in all buildings to be raised at least $300 \mathrm{~mm}$ from the ground, the surface water to be directed away from walls with a minimum ground level inclination of 1:20 and the area surrounding the foundations of buildings to be underdrained unless otherwise indicated through sufficient explanation.

Likewise, the regulations require a layer of at least $200 \mathrm{~mm}$ in thickness to stop capillary water rising under base floors. Furthermore, the regulations require thermal insulation to be placed entirely or mostly under a ground-supported floor slab. Clear designing instructions are given for the ventilation of base floors with crawl spaces. Similarly, the regulations require functional waterproofing for the floor and walls of wet areas. A minimum inclination of 1:40 is required for roofs and the construction of eaves is recommended. Cellar walls must have functioning 
waterproofing. In addition, the regulations require pipework to be located so that possible water leaks are noticed sufficiently early (Ministry of the Environment, 1998, 1999). With these regulations it is possible to intervene in all the typical causes of moisture damage.

In Finland, attention also has been given to the proper use and service of buildings. Building regulations require that a user and service guide is written for all buildings (Ministry of the Environment, 2000). As they are updated, the building regulations also pay increasingly more attention to the quality of the design. Based on the difficulty of the construction project, building codes specify the required qualifications of various designers, which consist of education as well as experience. The building's physical design is specified as an important area of structural design and expert design is required for buildings that are physically demanding moisture (Ministry of the Environment, 2002). These building codes will improve the quality of building design and usage as well as service and thus will reduce partially the risk of moisture damage.

\section{SUMMARY}

The majority of Finnish single-family houses are wooden structures. Historically, a large amount of moisture damage has occurred in singlefamily houses. The damage is not caused so much by wood as a building material but by structural defects. Wood is a demanding building material with respect to moisture engineering and requires reliable structural protection (see Figure 8). Risky structures were used particularly in the second half of the 1900s. The greatest risks relate to base floor structures, the joint between the floor and the exterior wall and wet areas. Despite an

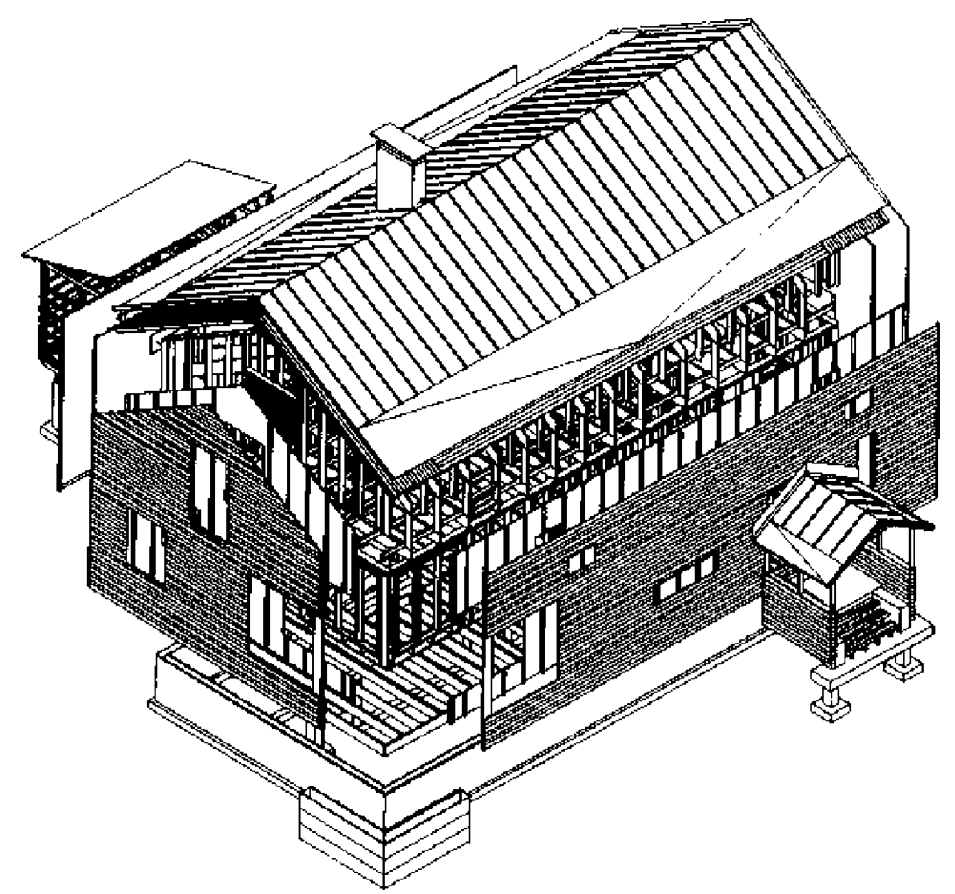

Figure 8: A modern Finnish wooden house with safe and sound wooden structures 
increase in information, the same incorrect decisions are repeated time and time again in actual construction.

After a lot of damage, economic loss and extensive discussion of construction quality, Finland has learned its lesson about construction errors. Individual regulations concerning moisture technique solutions have been written into Finnish building codes. The design, use and maintenance of buildings is regulated more carefully than before through these building codes. The goal of these rather tough measures is to stop unnecessary moisture damage resulting from mere ignorance and this is likely to be achieved because the regulations are directed at the key problems and intervene in the principal risk structures. The regulations have been in effect for so short a time that there is not yet available feedback about their effects. When it is possible to clamp down on structural flaws, the traditional Finnish material — wood - will be free of the unjustified suspicion directed at it. When the structure of wood is properly protected it is a long-lasting and reliable material that creates beauty, warmth and pleasantness in its surroundings.

\section{References}

Kääriäinen, H., Rantamäki, J. and Tulla, K. (1998) Puurakenteiden Kosteustekninen Toimivuus. Kokemustiedot (Functionality of Moisture Technique in Wood Structures. Experience Data). [in Finnish], VTT, Espoo, Finland.

Koivisto, J., Jääskeläinen, E., Nevalainen, A., Husman, T., Meklin, T., Vahteristo, M., Heiskala, S., Forss, P., Turpeinen, J and Röning-Jokinen, I. (1996) Asuinkerrostalojen Kosteusvauriot — Yleisyyden ja Korjauskustannusten Selvittäminen (Moisture Damage in Apartment Buildings Clarification of the Frequency and Cost of Repairs). [in Finnish], Kansanterveyslaitoksen Julkaisuja, Publications of the National Public Health Institute, Kuopio, Finland.

Määttä, J. and Kannisto, T. (1997) Pientalojen Talousvesiverkostojen Vuotovahingot (Leaking Damage of Single-family Houses' Household Water Network). [in Finnish], VTT, Espoo, Finland.

Ministry of the Environment (1998) Ympäristöministeriö. Kosteus. Määräykset ja Ohjeet. Suomen Rakentamismääräyskokoelma C2 (Moisture. Regulations and Guides. The National Building Code of Finland C2), Ministry of the Environment, Helsinki, Finland.

Ministry of the Environment (1999) Ympäristöministeriö. Kosteus Rakentamisessa. Ympäristöopas 51 (Moisture in Construction. Environmental Guide 51). [in Finnish], Ministry of the Environment, Tampere, Finland.

Ministry of the Environment (2000) Ympäristöministeriö. Rakennuksen Käyttö-ja Huolto-ohje. Määräykset ja Ohjeet. Suomen Rakentamismääräyskokoelma A4 (Building Use and Maintenance Guide. Regulations and Guides. The National Building Code of Finland A4), Ministry of the Environment, Helsinki, Finland.

Ministry of the Environment (2002) Ympäristöministeriö. Rakennuksen Suunnittelijat ja Suunnitelmat. Määräykset ja Ohjeet. Suomen Rakentamismääräyskokoelma A2 (Building Planners and Plans. Regulations and Guides. The National Building Code of Finland A2), Ministry of the Environment, Helsinki, Finland.

Partanen, P., Jääskeläinen, E., Nevalainen, A., Husman, T., Hyrärinen, A., Korhonen, L and Melkin, T. (1995) Pientalojen Kosteusvauriot - Yleisyyden ja Korjauskustannusten Selvittäminen (Moisture Damage in Single-family Houses - Clarification of the Frequency and Cost of Repairs). [in Finnish], Kansanterveyslaitoksen Julkaisuja, Publications of the National Public Health Institute, Kuopio, Finland.

Soikkeli, A. (1999) Suomalaisten Puujulkisivujen Pitkäaikaiskestävyys (Long-term Durability of Finnish Wooden Façades), [in Finnish] University of Oulu, Department of Architective, Oulu, Finland. 